-动态信息・

\title{
遗传资源获取和利益分享与知识产权保护
}

\author{
吴小敏 ${ }^{1}$ 徐海根 ${ }^{1}$ 朱成松 $^{2}$ \\ 1 (国家环境保护总局南京环境科学研究所，南京 210042) \\ 2 (江苏省农业科学院经济作物研究所, 南京 210014)
}

摘要：随着人类对遗传资源开发利用程度的加剧、物种资源不断减少以及国际交流合作的日益频繁,遗传资源获取 和利益分享中的知识产权问题日益受到国际社会的关注。为了保护和持续利用遗传资源，本文根据《生物多样性 公约》第 15 条的规定，以及国际社会在遗传资源获取和利益分享方面的做法，分析了我国遗传资源保护和利用以 及知识产权保护的现状, 提出建立和完善保护遗传资源知识产权的专利制度、遗传资源的管理制度以及遗传资源 保护和利用的市场化机制等管理措施。最后，对中国和阿根廷 NIDERA 公司在大豆遗传资源交换、合作研究和利 益分享的案例进行了分析。

关键词：遗传资源保护，管理制度，案例分析

中图分类号 :S32 文献标识码 : A 文章编号 : 1005-0094(2002)02-0243-04

\section{Access to and benefit sharing from genetic resources and protection of intellectual property rights}

WU Xiao-Min ${ }^{1}$, XU Hai-Gen ${ }^{1}$, ZHU Cheng-Song ${ }^{2}$

1 Nanjing Institute of Environmental Science, State Environmental Protection Administration of China, Nanjing 210042

2 Institute of Industrial Crops , Jiangsu Academy of Agricultural Sciences , Nanjing 210014

\begin{abstract}
With excessive utilization of genetic resources, decline of biological species resources and the increase of international exchange and cooperation, issues of access to intellectual property and sharing of benefits from genetic resources have received greater attention from the international community. Based on clause 15 of the Convention on Biological Diversity and the general practice for access to and benefit sharing from genetic resources in the international community, the present situation of protecting and utilizing genetic resources in China and the relationship with intellectual property rights were analyzed. Establishment and improvement of the patent system for intellectual property, the management system and the market mechanism for the conservation and utilization of genetic resources are proposed for the purposes of protecting and sustainably utilizing genetic resources. Finally a case study on the access to and benefit sharing of soybean genetic resources between a Chinese company and the Argentinian NIDERA company is analyzed.
\end{abstract}

Key words : genetic resources protection, management rules, case study

\section{1 遗传资源获取和利益分享与知识产权保护现状}

如何通过适当的机制获得和利用遗传资源, 并分享其产 生的利益,已成为当前世界各国普遍关心的重要问题之一。 由于这一问题涉及到知识产权、国际贸易和经济利益问题, 因而引起了国际社会和各国政府的高度重视。《生物多样性 公约》将遗传资源获取和利益分享作为三大目标之一, 公约 第 15 条要求每一缔约国应致力于创造条件,以利于其他缔 约国取得遗传资源用于无害环境的用途，并规定遗传资源的
取得须经提供这种资源的缔约国事先知情并同意, 再按照共 同商定的条件进行。取得资源的缔约国应与提供资源的国 家公平分享研究和开发此资源而获得的成果和利益 (薛达 元, 高振宁 ,1995)。为了解决遗传资源的获取和交换问题, 联合国粮农组织制定了《粮农植物遗传资源的国际承诺》 ( International Promises on Plant Genetic Resources for Food and Agriculture) 和《国际植物种质收集和转移守则》 (International Plant Genes Collection and Transference Regulations) ,规 
定了上述两个条约的缔约国应当遵守的标准和原则, 并提出 了分享利益的若干机制 (娄希让, 1996) , 其目的是促进遗传 资源的合理收集和可持续利用，保护种质资源捐献者和收集 者的利益。我国是遗传资源的重要原产国和供应国，平均每 年向国外免费提供 2000 余份作物种质资源; 同时又是主要 的遗传资源输入国，从国外引进大量的种质资源用于植物育 种和农业生产，国外遗传资源的引进对中国的农业、林业、医 药和生物多样性保护起到了非常重要的作用。

目前, 由于世界各国对遗传资源获取和利益分享缺乏有 效的机制和规范的操作程序，特别是国际社会在遗传资源的 国家所有权、遗传资源的获取方式与条件以及遗传资源效益 的公平分享等几大问题上还存在较大的争议和分歧, 同时又 缺少相应的市场化机制，这在某种程度上限制了遗传资源的 广泛交换和利用。随着物种资源的不断减少和因生物技术 迅猛发展对遗传资源需求的不断增加，遗传资源逐步由公共 物品转变为稀缺物品。遗传资源获取和利益分享中的知识 产权问题日益受到国际社会的广泛关注。为此, 需要根据 《生物多样性公约》的规定，结合我国国情和国际背景，建立 和完善遗传资源获取和利益分享机制及其相关的知识产权 保护制度。

\section{2 遗传资源获取和利益分享管理法规与知识产权 制度的关系}

\section{1 我国遗传资源管理法规的主要内容}

为了加强对遗传资源的保护与管理, 维护国家、企事业 单位以及科技人员的合法权益，促进农业、林业和医药生产， 保护遗传资源的安全，我国政府相继颁布了一系列涉及遗传 资源保护和利用的政策法规。国务院于 1994 年 4 月颁布了 《种畜禽管理条例》, 1995 年颁布了《中华人民共和国进出境 动植物检疫法》, 1996 年 9 月颁布了《野生植物保护条例》, 1997 年 3 月颁布了《中华人民共和国植物新品种保护条 例》。2000年 7 月, 全国人大常委会通过了《中华人民共和 国种子法》。

为了与人大常委会和国务院颁布的法规相配套, 农业部 于 1998 年 1 月颁布了《种畜禽管理条例实施细则》,1999 年 4 月颁布了《植物新品种保护条例实施细则》(农业部分) 和 《农业植物新品种保护名录 (第一批)》; 国家林业局于 1999 年 8 月颁布了《植物新品种保护条例实施细则》(林业部 分）,并分别于 1999 年 4 月和 2000 年 2 月发布《林业植物新 品种保护名录 (第一批)》和《林业植物新品种保护名录 ( 第 二批)》等法规和条例。此外，农业部于 1991 年 6 月颁布了 《中华人民共和国种子管理条例》和《农作物种子管理实施 细则》,于 1997 年 3 月颁布了《进出口农作物种子 (苗) 管理 暂行办法》,1997 年颁布了《外商投资农作物种子企业审批 和管理规定》,1998 年 4 月颁布了《农作物种子生产经营管 理暂行办法》2001年 2 月颁布了《主要全国农作物品种审 定办法》等管理法规; 林业部在 1987 年就颁布了《野生药材
资源保护管理条例》;国家出入境检疫局也于 1999 年 12 月 颁布了《进境植物繁殖材料检疫管理办法》。这些法规对遗 传资源的管理和保护措施、对遗传资源拥有者的权利和利益 以及遗传资源的对外交流与合作都作了比较明确的规定。

我国的法规对种质资源的保护、品种的选育、审定和使 用作出了一般性的规定。《中华人民共和国种子法》规定， 国务院农业、林业行政主管部门分别主管本行政区域内农作 物种子和林木种子工作。对农作物种子经营实行许可证制 度, 种子经营者必须取得种子经营许可证, 并在工商行政管 理机关办理营业执照后方可出售或生产。《全国农作物品种 审定办法》规定:由国务院和省、自治区、直辖市人民政府的 农业行政主管部门设立由专业人员组成的农作物品种审定 委员会, 承担主要农作物品种的审定工作。并对申报条件、 申报程序、品种审定等事项作出了具体规定。

我国的法规对植物新品种育种人的权利、义务、责任和 利益作出了原则性的规定。例如，《中华人民共和国种子 法》中规定: 国家实行植物新品种保护制度, 保护植物品种权 益人的合法权益。选育的品种得到推广应用的, 育种者可依 法获得相应的经济利益。

最后, 这些法规对种子的进出口和对外合作等事项的管 理作出了比较明确的规定。例如, 《进出口农作物种子 (苗) 管理暂行办法》规定: 向国 (境) 外提供种质资源, 按照作物 种质资源分类目录管理, 由中国农业科学院品种资源研究所 办理审批手续,国务院农业行政主管部门审批。

\section{2 现行遗传资源管理法规存在的主要问题}

长期以来, 我国对遗传资源实行统一与分级分部门相结 合的管理模式及由各部门起草法律条文的立法方式, 缺乏遗 传资源立法的整体思想和总体规划, 因此, 在许多方面已不 能适应遗传资源保护和发展的需要。主要表现在下列 2 个 方面:

1) 已有法律法规体系尚不完善。我国目前缺乏综合的 遗传资源管理法, 同时现有的法规也没有涵盖遗传资源的所 有内容, 如尚未制定渔业、海洋等遗传资源管理法规等。我 国的一些遗传资源管理法规明文规定了对植物新品种的保 护, 但没有明确规定对动物和微生物新品种的保护。其次, 遗传资源单项法规的管理范围和覆盖面也有不足。例如, 现 行的与遗传资源相关的法规主要强调生物品种的保护, 而忽 略了遗传资源和遗传能力的保护, 如对生物遗传基因和转基 因生物品种的保护; 《植物新品种保护条例》注重对植物品 种权和和品种权益人的保护, 而对遗传资源使用和交换活动 中存在的权属属性的规定很少。对地方社区和农民长期保 存和使用的地方品种的保护措施也没有明确的规定。另外， 我国现有的与遗传资源管理相关的法规, 很少涉及与促进和 繁㭉遗传资源开发和交流等方面的内容, 如遗传资源使用和 交换的市场化机制等方面的规定很少。

2 ) 部分条文内容过于原则化, 缺乏可操作性的管理措 
施。我国目前的与遗传资源相关的管理法规主要是从本部 门或行业的保护和使用情况出发, 更多地立足于强调行政管 理手段以及一些原则性的管理规定和运行程序, 缺乏保护遗 传资源明确的法律制度和具体有力的措施，从而使这些法规 的实际操作性较差。如《种子法》对植物品种的选育以及在 种子生产、经营和使用过程中, 品种选育者、生产者、经营者 和使用者的权利提出了一些原则规定，但没有对植物种子的 保护范围和具体的保护措施作出比较明确的管理规定, 特别 是在种子使用过程中，作物品种的权益方、使用方和转让方 之间的利益分享机制和冲突的解决方式等也没有明确的规 定。《植物新品种保护条例》强调对植物品种权的保护, 而 忽视使用权的制定，特别是对植物新品种的应用范围、转让 的具体规定、限制条件以及使用补偿等问题都缺少具体的可 操作性的条文和规定。

3 遗传资源获取和利益分享中的知识产权保护措 施

\section{1 更新补充现有法律法规的内容}

针对现有与遗传资源相关法规的不足之处, 建议增加和 补充下列内容 :

1) 补充和完善遗传资源管理制度方面的内容, 要明确涉 及的人员和部门, 以及各部门的管理领域和范围, 特别要对 重叠管理的遗传资源划定明确的管理关系。同时, 要建立和 补充遗传资源产权制度、有偿使用制度、补偿制度、交易制度 等基本法规。规定提供和转让遗传资源的条件、申报审批程 序、归口管理部门及其具体的职责和权限 ;

2 ) 建立和完善遗传资源获取和利益分享机制。明确遗 传资源的取得是否经 事先知情同意”, 哪些遗传资源须经 事先知情同意; 明确规定提供和转让遗传资源的应用范围和 用途性质，包括科研用途和商业用途等，对不同用途采取不 同的政策;明确规定转让的具体条件，包括可取得和转让的 优惠条件, 特别是所转让的材料是否可提供给第三方, 是否 可进行商品化 (靳晓白，1999）; 明确规定在遗传资源的使用 和转让过程中各种权益的界定和利益分配办法等。

\section{2 建立和完善保护遗传资源知识产权的专利制度}

要按照《生物多样性公约》和国内外知识产权保护法规 的要求和规定，建立和完善保护遗传资源知识产权的专利制 度。坚持遗传资源的国家主权和公平分享的原则，保证遗传 资源的安全, 保护遗传资源拥有者和使用者的权利。为此, 需要建立和完善下列知识产权保护制度：

1) 开展遗传资源的调查工作,查清我国遗传资源的种 类、数量、利用方式以及获取和被获取的现状及其产生的效 益。对涉及农业、林业、海洋、医药及环境等广泛领域的具有 实用价值和商业化前景的原产于我国的遗传材料及动植物 新品种列入知识产权保护范畴。对植物新品种，建立与专利 保护配套的相关法规，实施对育种方法和品种权的双重保 护; 对动物和微生物新品种，建立专利程序下的繁殖材料 (如
动物的卵子、精子或受精卵) 保藏制度, 以及提供该动物和微 生物新品种特征的基因图谱制度。同时, 将遗传资源中的遗 传能力与遗传材料的主体分开, 除极少数涉及国家主权的物 种外，规定在中国领域内实际已存在一定年限的生物资源的 遗传能力都为公有资源, 以鼓励研究开发和创新, 减少各方 的冲突 ;

2 ) 要研究、整理我国地方社区, 尤其是少数民族地区农 民在创造、使用和保存地方土著优良品种方面的传统技术、 知识和做法, 并将它们列入知识产权保护范畴(薛达元, 1997)。要制定利用常规技术或传统技术获得的地方优良品 种的保护措施、使用补偿问题, 以及鼓励当地社区和农民保 护和利用地方土著品种的措施;

3) 要进一步明确遗传资源的产权归属以及使用人和转 让人的权利和义务; 要建立和完善造成损失方和受损失方的 协商机制, 规定对遗传资源开发利用中所产生争议的协商调 解办法, 一般的限制条件, 包括对将来利用的限制、对进出口 的限制以及对环境无害的具体限制, 明确违及“条例” 有关 规定的法律责任。

\section{3 建立和完善遗传资源保护与利用的市场化机制}

遗传资源保护与利用的市场化机制涉及到各国的知识 产权保护和经济利益。因此, 在鼓励开展国际合作, 促进技 术和人员交流，促进遗传资源交换和成果共享的同时,要建 立和完善遗传资源利益分享的交换机制和行为准则来保证 各国的权利和利益。

在完善现有国际多边体系的基础上, 要充分利用市场化 保护与利用机制, 积极开展以遗传资源获取和交换方式为基 础的多边形式的国际合作 (陆文聪, 倪琪, 2000)。要按照市 场需求，建立和完善遗传资源交换和服务机构的功能和作 用, 要按照市场需求, 强化遗传资源中介服务的功能和作用, 遗传资源中介服务要以遗传资源供求双方在资金补偿、技术 合作和知识产权保护方面达成双边协议为目标, 鼓励有关各 方建立良好的行为规范和信赖关系, 互相成为优先合作伙 伴, 促进国际合作, 公平分享科研成果和经济利益。

\section{4 遗传资源获取和利益分享的案例分析}

\section{1 中国和阿根廷 NIDERA 公司大豆遗传资源交换案例}

中国和阿根廷都是《生物多样性公约》的缔约国，也是 世界主要的大豆生产和科研大国, 中国还是大豆遗传资源最 丰富的国家之一。近几十年来, 人类经济活动的干扰以及农 业生态环境的恶化对大豆种质资源产生了严重的威胁。大 豆病虫害是目前大豆生产中面临的主要问题, 关系到两国农 业发展和环境保护问题。

中国江苏省农业科学院下属的经济作物研究所是专门 从事大豆、油料等经济作物的研究机构。该所朱成松领导的 研究小组经过多年的努力, 培育了转 $B t$ 基因大豆品种。阿 根廷 NIDERA 公司主要经营农产品和海产品的贸易、种子生 产和遗传资源的研究, 是世界上最大的种子开发和贸易公司 
之一,该公司于 20 世纪 90 年代末从美国 Momsanto 公司引 进了抗草甘膦大豆品种的专利。为了吸收两国的成功经验， 推动两国大豆生产和科研的发展, 江苏省农业科学院和阿根 廷 NIDERA 公司开展了大豆种质资源交换和合作研究。双 方的合作从科技交流活动开始，1999 年 8 月 4 日在美国芝加 哥召开的第 6 届世界大豆研究会议上, 江苏省农科院经济作 物研究所朱成松作了题为 含有 Bt 内毒素蛋白的转基因大 豆作物”报告, 引起了参加会议的阿根廷 NIDERA 公司代表 的兴趣，并表示希望得到中国的转 $B t$ 基因抗虫大豆品种。 在得到农业部正式同意后, 朱成松开始与阿根廷 NIDERA 公 司副总裁兼阿根廷驻中国大使馆商务参赞 Raul Loeb 先生商 谈合作事项。在阿根廷 NIDERA 公司考察过程中, 朱成松了 解到阿根廷 NIDERA 公司从美国 Monsanto 公司引进并购买 了抗草甘膦大豆品种的专利 ${ }^{\circledR}$,所以中方提出用转 $B t$ 基因抗 虫大豆品种交换 NIDERA 公司的抗草甘膦大豆品种, 得到了 NIDERA 公司的同意，从而双方开始大豆遗传资源的交换和 合作研究。

根据合作协议的规定, 中国江苏省农科院经济作物所向 NIDERA 公司提供转 $B t$ 基因抗虫大豆品种及相关技术， NIDERA 公司向中国江苏省农科院提供大豆抗除草剂品种 及其相关技术。江苏省农业科学院和阿根廷 NIDERA 公司 对各自拥有的大豆种质资源享有知识产权和向对方提供该 品种的权利，双方合作研究的内容主要包括大豆遗传资源的 农学性状和分子遗传学研究。农学性状研究主要有大豆抗 虫特性的观察、鉴定和评估, 分别在江苏省农业科学院和阿 根廷 NIDERA 公司进行。分子遗传学研究主要有大豆抗除 草剂基因的利用和分子育种等研究, 主要在阿根廷 NIDERA 公司的生物技术实验室进行。双方定期交换信息, 并共同分 享合作研究的成果和由此产生的效益。

江苏省农科院从阿根廷 NIDERA 公司获取了9 个抗草 甘膦大豆品种, 并于 2000 年 6 月在江苏、广西、河南和海南 4 省 (区) 进行试种和推广。田间试验结果表明, 引进的抗除 草剂大豆品种不仅抗除草剂效果好、适应性强, 而且产量高, 每公顷产量为 2700 多公斤, 比国内大豆产量高出 450 多公 斤, 每公顷大豆可增加收入近 1200 元人民币，具有较高的经 济价值。通过对转 $B t$ 基因抗虫大豆和抗除草剂大豆遗传材 料的研究, 可以了解抗虫和抗除草剂基因的特性, 利用这些 大豆品种作为遗传亲本材料，与其他大豆品种杂交，可以选 育出适应性好、产量高、能抗虫和抗除草剂的大豆新品种。 采用抗除草剂和抗虫的大豆品种, 还可减少农药的使用量， 减轻对环境的污染, 不仅有利于人体的健康和安全, 而且也 有利于物种多样性的保护。

\section{2 案例分析和评估}

该案例是一次在政府管理部门、科研单位和种子公司共 同参与下完成的大豆种质资源的跨国交换活动，整个过程是 从科技交流开始，经过合作双方的协商和谈判，签署合作协
议, 最后进入实施阶段。这一过程充分体现了平等和公正的 原则。

两国政府充分认识到农业遗传资源的重要性，多年来， 两国政府在农业遗传资源的保护和利用方面开展了大量工 作。同时, 两国政府比较重视知识产权保护工作, 制定了一 些有效的农业遗传资源保护法规和管理制度。两国的科研 和生产企业重视大豆品种资源的研究、引进和开发工作, 从 而保证了双方在大豆遗传资源的获取、谈判、交换和研究等 各阶段的合作能顺利的开展。双方在大豆遗传资源利益的 分配问题上, 制定了合理的行为准则, 在一定程度上规范了 大豆种质资源的获取和利益共享的交易行为。利益共享不 仅表现在直接的物质形式的利益共享, 如共享遗传资源, 也 表现在促进科研工作的开展以及知识和信息的交流上。

双方的这种合作有力地促进了两国大豆遗传资源的科 研工作，提高了两国的粮食生产和促进经济发展。这种合作 不仅符合《生物多样性公约》的精神, 也符合两国的共同利 益, 对两国的生态、经济和社会的发展将产生深远的影响。

今后需要改进的方面：

1 ) 进一步明确农业遗传资源获取方式与技术标准。由 于中国和阿根廷两国具有不同的技术标准，如农业种质资源 的卫生检疫标准和措施不同, 在合作协议中应明确所依据的 国际标准、准则或建议, 并确保人类和动植物生命健康;

2) 利益分享是遗传资源获取和交换的最重要的问题之 一,合作协议对大豆遗传资源的获取方式、合作研究和经济 利益方面的规定比较具体, 对大豆遗传资源的专利权和利益 分享的安排只作了原则性的规定。因此, 需要进一步对品种 权益人权利和利益, 各种权益的界定、分配和保护政策, 特别 是用于商业性生产和转让第三国的权利和利益分配, 以及对 违约侵权的责任和处罚都应该明确规定；

3) 对转基因大豆品种的释放对于人体和环境的影响以 及生物安全处理方法等问题也应作出相应的规定。

\section{参考文献}

薛达元, 高振宁, 1995. 《生物多样性公约》技术评注与履行 策略. 北京: 中国环境科学出版社

娄希让, 1996. 联合国粮农组织第六届植物遗传资源委员会 会议情况. 《作物品种资源》,(2):46 47

靳晓白, 1999. 遗传资源取得和利益分享的植物园政策探索 项目与共同政策准则. 《生物多样性》,(3) $255 \sim 256$

薛达元, 1997. 论遗传资源保护的国家策略. 《自然资源学 报》, (1) $55 \sim 58$

陆文聪, 倪琪, 2000. 植物遗传资源保护与利用的市场化机 制和国际制度. 《自然资源学报》,(3): 285 288

(责任编辑 : 时意专) 